\title{
High rate anaerobic treatment of Sago wastewater using HUASB with PUF as carrier
}

\author{
${ }^{1 *}$ J. Rajesh Banu, ${ }^{2}$ S. Kaliappan and ${ }^{3}$ D. Beck \\ ${ }^{1}$ Department of Biotechnology, Jeppiaar Engineering College Chennai, India \\ ${ }^{2}$ Centre for Environmental Studies (CES), Anna University, Chennai- 600025 India \\ ${ }^{3}$ Senior Advisor, Indo-German Project, CES
}

Received 4 November 2005;

revised 18 February 2006;

accepted 3 March 2006

available online 18 April 2006

\begin{abstract}
Sago industry is one of the major small-scale sectors in India and over 800 units are located in the southern State of Tamilnadu. Processing of sago generates enormous quantities of high strength wastewater requiring systematic treatment prior to disposal. The present study is an attempt to treat the sago wastewater using Hybrid Upflow Anaerobic Sludge Blanket (HUASB) reactor, which offers the advantages of both fixed film and up flow anaerobic sludge blanket treatment. HUASB reactor with a volume of $5.6 \mathrm{~L}$ was operated at Organic Loading Rates varying from 10.7 to $24.7 \mathrm{~kg} \mathrm{COD} / \mathrm{m}^{3}$.day. After 130 days of startup, the reactor produced appreciable decrease in COD of wastewater and removed solids efficiently. The COD removal varied from 91-87\%. While the removal of Total Solids was in the range of $61-57 \%$, that of volatile solids varied from $70-67 \%$. The ideal OLR for the reactor was 23.5 $\mathrm{kg} \mathrm{COD} / \mathrm{m}^{3}$.day. The findings of the study open up newer possibilities of design low cost and compact onsite treatment systems with very short retention periods.
\end{abstract}

Key words: Sago effluent, HUASB, treatment efficiency, biogas

*Corresponding Author, E-mail: rajeshces@gmail.com.

\section{INTRODUCTION}

Sago, the common edible starch in the form of globules is processed from the tubers of tapioca (Mannihot utillisema). Processing of tapioca requires 20,000 to $30,000 \mathrm{~L}$ of water per ton of Sago; besides it produces equal quantity of wastewater, which is highly organic, foul smelling and acidic (Murthy and Patel, 1961; Sastry and Mohan, 1963). Various anaerobic technologies including conventional anaerobic treatment (Sastry et al., 1964; Tongkasane, 1970; Saroja and Sastry, 1972; Pescod and Thanh, 1977), high rate anaerobic treatment such as Anaerobic Filter (AF- Khageshan and Govindan, 1998) and Fluidized Bed (FB -Saravanane $e t$ al., 2001) have been attempted to treat Sago wastewater. The conventional treatment options are known to have low treatment efficiency owing to high concentrations of solids present in the wastewater. Published works indicate that most of the negative aspects of high rate anaerobic digestion can be overcome by restricting the supporting material to the top 25 to $30 \%$ of the reactor volume (Guiot and Van den berg, 1984; 1985). This would further help realize the advantages of both fixed film and up flow sludge blanket treatment. This kind of reactor often called Hybrid Up flow Anaerobic Sludge Blanket (HUASB) reactor and is considered more stable for the treatment of a series of soluble or partially soluble wastewaters (Tilche and Vieira, 1991). Over the years, HUASBs have been used to treat wastewaters from sugar industry (Coates and Colleran, 1990), pharmaceutical units (Hentry et al., 1996), distilleries (Shivayogimath and Ramanujam, 1999) and domestic sectors (Elmitwalli et al., 2002 a,b). In the present study, an attempt has been made to use the HUASB reactor to treat Sago wastewater.

\section{MATERIALS AND METHODS}

The Schematic of HUASB reactor is illustrated in Fig. 1. The laboratory scale reactor was fabricated using PVC tube with an internal diameter of $110 \mathrm{~cm}$ and an overall height of $87 \mathrm{~cm}$. Total volume of the empty reactor was $6.7 \mathrm{~L}$. A gas headspace equivalent to $1.5 \mathrm{~L}$ was maintained above the effluent line. A screen was placed at a height of $59 \mathrm{~cm}$ to arrest the floating packing material. A peristaltic pump (Make: Miclins PP20) was used for feeding the wastewater into the reactor. The 


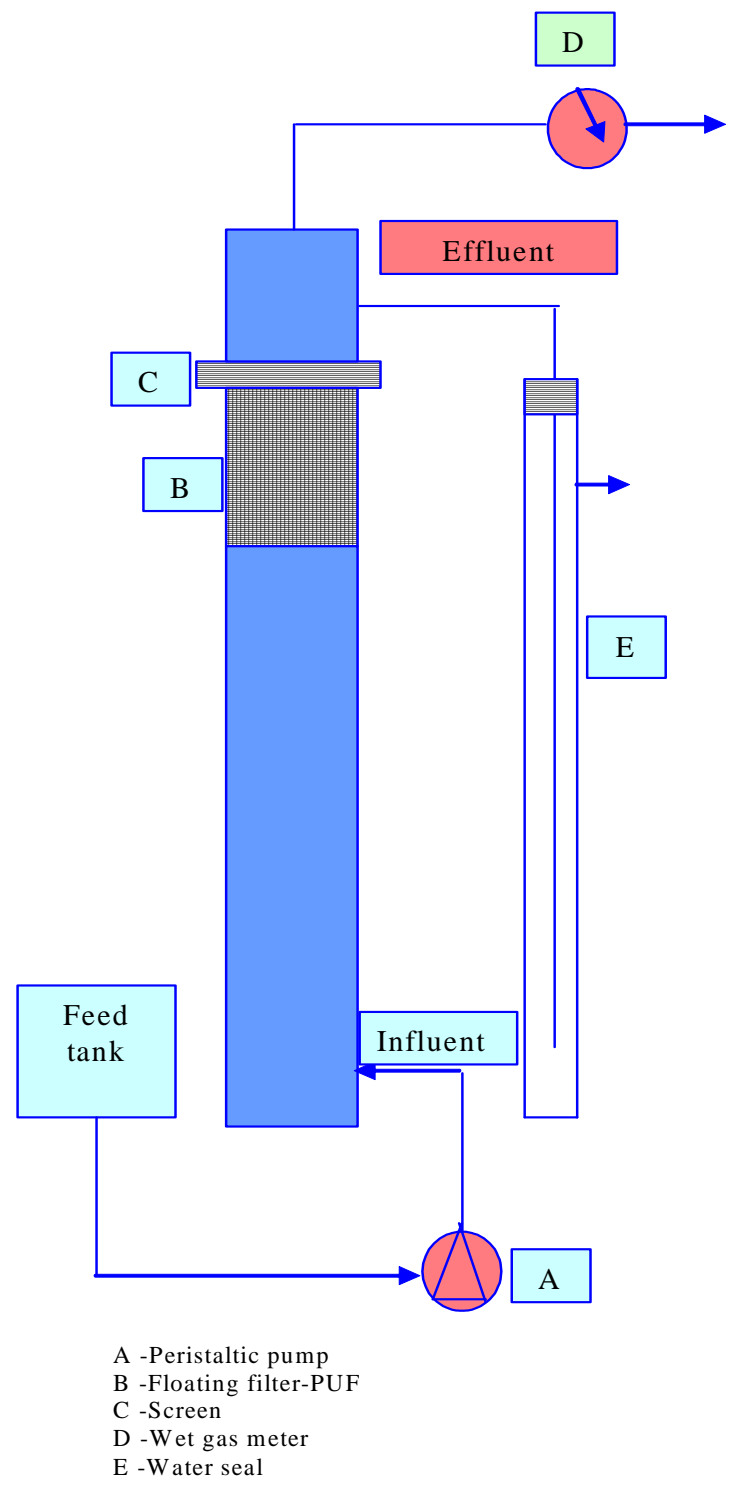

Fig. 1: Schematic diagram of the HUASB reactor

effluent pipeline intern was connected to a water seal to prevent the escape of gas. The gas outlet was connected to a wet gas meter (Make: Ritter. Model No: TG1)

\section{Carrier material}

Polyurethane foam (PUF) cubes 150 cubes each (measuring $2 \mathrm{~cm} \times 2 \mathrm{~cm} \times 2 \mathrm{~cm}$ ) was used as carrier material. Polyurethane is known to offer excellent colonization matrix in high rate reactors (Hysman et al., 1985) and entrap suspended solids in wastewater (Elmitwalli et al., 2002a) leading to an increase in the overall treatment efficiency.
Table 1: Physico-chemical characteristics of Sago wastewater

\begin{tabular}{ccc}
\hline Sl.No & Parameter & $\begin{array}{c}\text { Values* } \\
(\mathrm{mg} / \mathrm{L})\end{array}$ \\
\hline 1 & pH & 7.2 \\
2 & Total Solids & 7645 \\
3 & Suspended solids & 1405 \\
4 & Volatile solids & 1834 \\
5 & COD & 6000 \\
6 & BOD & 4800 \\
7 & TKN & 180 \\
8 & Chloride & 231 \\
9 & Sulphate & 87 \\
10 & Phosphate & 60 \\
11 & Potassium & 15 \\
\hline
\end{tabular}

All values except $\mathrm{pH}$ are in $\mathrm{mg} / \mathrm{L}$

* Average of triplicate

\section{Seed and inoculation}

Digested slurry from an active biogas plant located at Murugappa Chettiar Research Institute, Chennai was used as seed. To accelerate the start up, $40 \%(\mathrm{v} / \mathrm{v})$ slurry was mixed with the feed as recommended by Shapiro and Switzenbanum (1984) and Hickley et al., (1991).

\section{Sago effluent}

Synthetic wastewater was prepared by following Khageshan and Govindan (1995) and the physico chemical characteristics of the synthetic Sago wastewater was listed in Table 1.

\section{Start up phase}

During the start up, the reactor operation was initiated using wastewater with a COD of $2000 \mathrm{mg} / \mathrm{L}$. The initial retention time was $56 \mathrm{~h}$. The HRT was gradually decreased to $56 \mathrm{~h}$., which is equal to the volume of the reactor. This was achieved by increasing the flow rate from $100 \mathrm{~mL} / \mathrm{h}$ to $1000 \mathrm{~mL} / \mathrm{h}$ over a period of 130 days.

\section{Treatment phase}

After the start up, the reactor was operated by varying the influent Chemical Oxygen Demand (COD) at a constant HRT 5.6 h. The efficiency of the treatment was evaluated in terms of removal of Total Solids (TS), Volatile Solids (VS) and COD and generation of biogas.

\section{Chemical analysis}

COD, Volatile Fatty Acids as acetate (VFA), Total Alkalinity, TS, VS and Total Kjeldhal Nitrogen (TKN) 
of the raw and treated wastewater were analysed following Standard Methods (1998). Anions such as phosphate $\left(\mathrm{PO}_{4}^{3-}\right.$ ) sulphate $\left(\mathrm{SO}_{4}^{2-}\right)$ and chloride $\left(\mathrm{Cl}^{-}\right)$were analysed employing ion exchange chromatography(Make: Dionex, Model: DX120) after filtering the samples through a $0.45 \mu$ filter. The eluent was a combination of $3.5 \mathrm{mM}$ bicarbonate and $1 \mathrm{mM}$ carbonate; the flow rate was $1.2 \mathrm{~mL} /$ minute with an injection volume of $25 \mu \mathrm{L}$. Methane content in the biogas was measured by Gas Chromatography(Make: Chemito, Model: GC 1000) equipped with Flame Ionization Detector (FID). The column used was Proapak Q.

\section{RESULTS}

The loading regime and biogas production of the reactor during the start up phase are presented in the Fig. 2. The initial OLR applied during startup was $0.85 \mathrm{~kg}$ $\mathrm{COD} / \mathrm{m}^{3}$.day at a HRT of 56 hours. This HRT was preferred to prevent the washout of inoculated biomass (Hickely et al., 1991). When the OLR was increased in a stepped manner to $8.5 \mathrm{~kg} \mathrm{COD} / \mathrm{m}^{3}$.day over a period of 130 days, the biogas production also increased gradually reaching a maximum of $9.4 \mathrm{~L} /$ day at an OLR of $8.5 \mathrm{~kg} \mathrm{COD} / \mathrm{m}^{3}$.day. Fig. 3 presents COD removal and VFA accumulation pattern during startup period. The COD removal increased with time; this is in conformity with the findings of Saravanane et al., (2001) during the treatment of Sago wastewater. The VFA concentration in the effluent at the initial OLR $0.85 \mathrm{~kg} \mathrm{COD} / \mathrm{m}^{3}$.daywas in the range of 780-720 $\mathrm{mg} / \mathrm{L}$ from that it fell down to $548 \mathrm{mg} / \mathrm{L}$ at OLR $2.5 \mathrm{~kg} \mathrm{COD} /$ $\mathrm{m}^{3}$.day. Higher levels of VFA in the wastewaters during the initial phases of operation indicate the prevalence of acid fermentation (Van Hanndel and Lettinga, 1994). Subsequently, the VFA in the wastewater decreased and was in the range of 525 to $447 \mathrm{mg} / \mathrm{L}$ indicating healthy anaerobic environment and satisfactory methanogenic activity. The overall performance of the reactor during the start-up was more than satisfactory. It is known that selection of seed material plays a crucial rolein minimizing timerequired for initial bioflim establishment (Bull et al., 1983; Salkinoja - Salonen et al., 1983). It is likely that the slurrycollected from an activebiogas plant and used as a seed had sufficient numbers of physiologically active microorganisms.

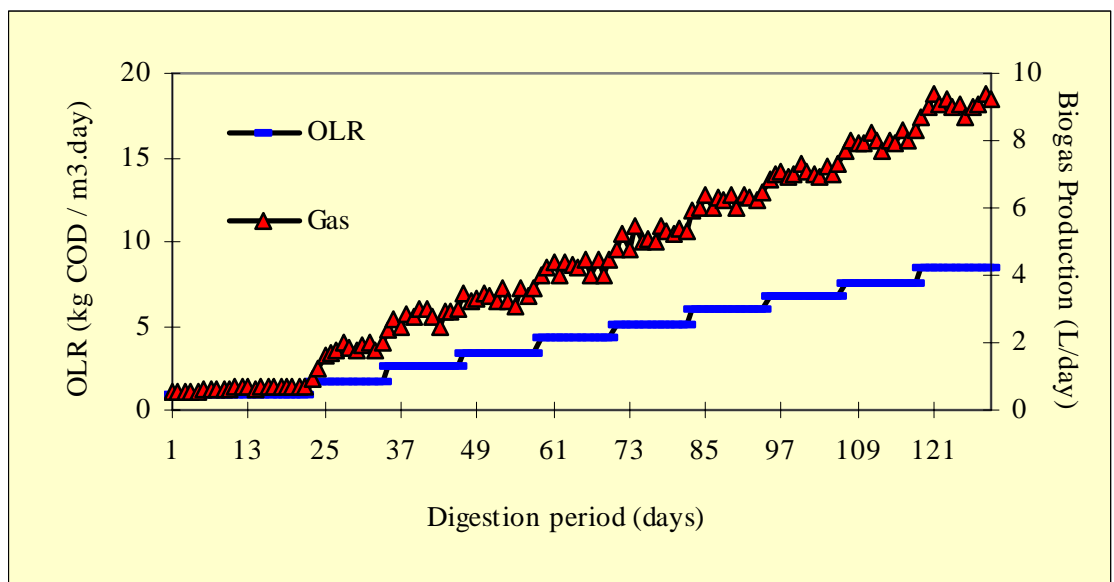

Fig. 2: Organic loading pattern and biogas produciton during the startup of HUASB treating Sago wastewater

Treatment phase

Fig. 4 illustrates the loading pattern and biogas production during the treatment. The initial OLR applied during this phase (Day-131) was $10.7 \mathrm{~kg}$ COD/m³ day. It was increased in a stepped manner to $24.7 \mathrm{~kg}$ COD/ $\mathrm{m}^{3}$.day over a period of 245 days. The increment between successive OLR was about $2.1 \mathrm{~kg} \mathrm{COD} / \mathrm{m}^{3}$.day. The gas production increased as the OLR increased, reaching a maximum $28.2 \mathrm{~m}^{3} /$ day at an OLR of $23.5 \mathrm{~kg}$ $\mathrm{COD} / \mathrm{m}^{3}$.day. Beyond this loading, the gas production decreased with increase in OLR (24.7 kg COD/m³.day). Table 2 presents data on Normalized Methane
Production (NMP), and methane content of biogas at various phases. It is evident from the Table that at an OLR of $10.7 \mathrm{~kg} \mathrm{COD} / \mathrm{m}^{3}$.day the NMP and methane content of the reactor were $0.11 \mathrm{~m}^{3} \mathrm{CH}_{4} / \mathrm{Kg}$ COD.day and $65 \pm 3$, respectively. As the OLR increased, the NMP exhibited a gradual increase; at an OLR of $23.5 \mathrm{~kg} \mathrm{COD/}$ $\mathrm{m}^{3}$.day, the NMP reached a maximum of $0.13 \mathrm{~m}^{3} \mathrm{CH}_{4} / \mathrm{Kg}$ COD.day. The NMP and methane content of biogas touched an all time low of $0.06 \mathrm{~m}^{3} \mathrm{CH}_{4} / \mathrm{Kg}$ COD.day and $55 \pm 2$, respectively when the OLR was increased to 24.7 $\mathrm{kg} \mathrm{COD} / \mathrm{m}^{3}$.day. 
R. Banu, et al.

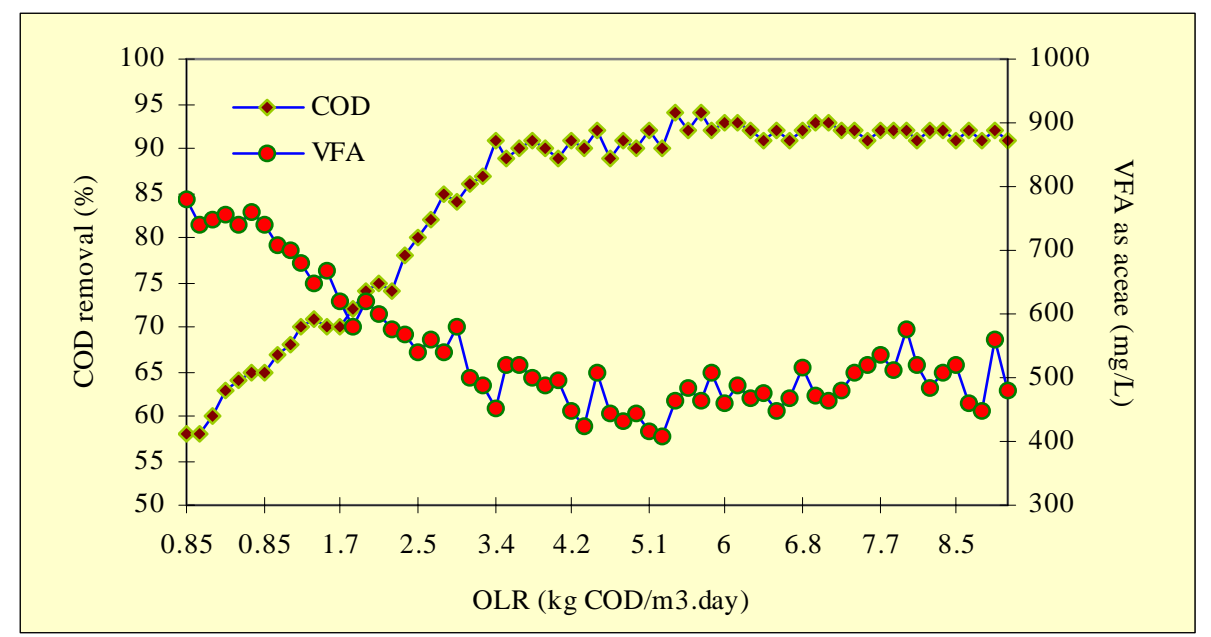

Fig. 3: Influence of OLR on COD removal and VFA accumulation during the startup of HUASB treating synthetic Sago wastewater

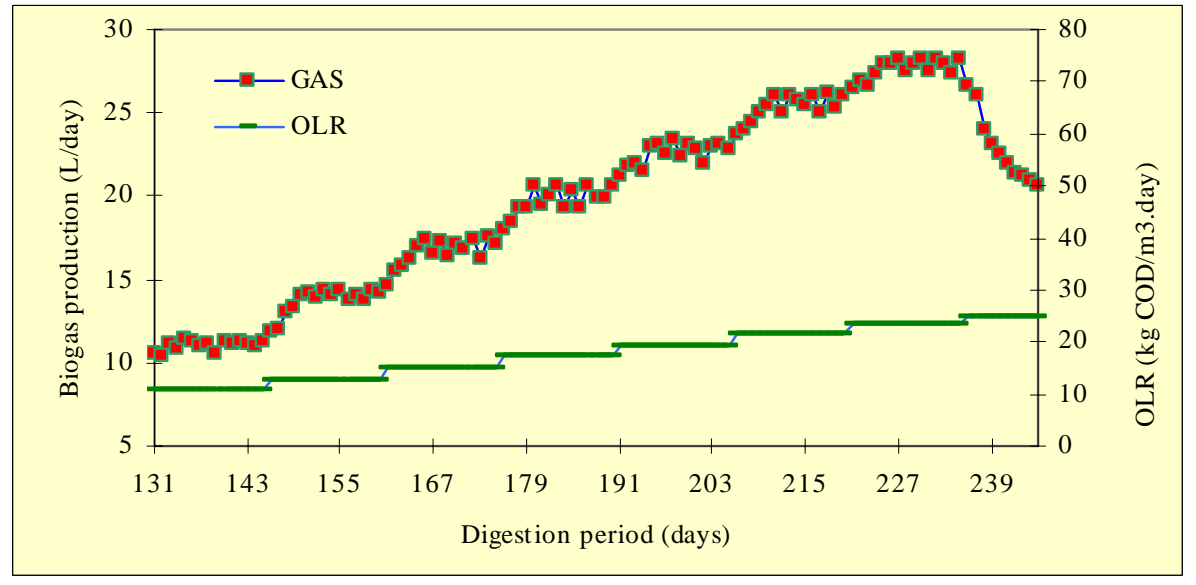

Fig. 4: Organic Loading pattern and biogas prodution during the treatment phase of HUASB treating synthetic Sago wastewater

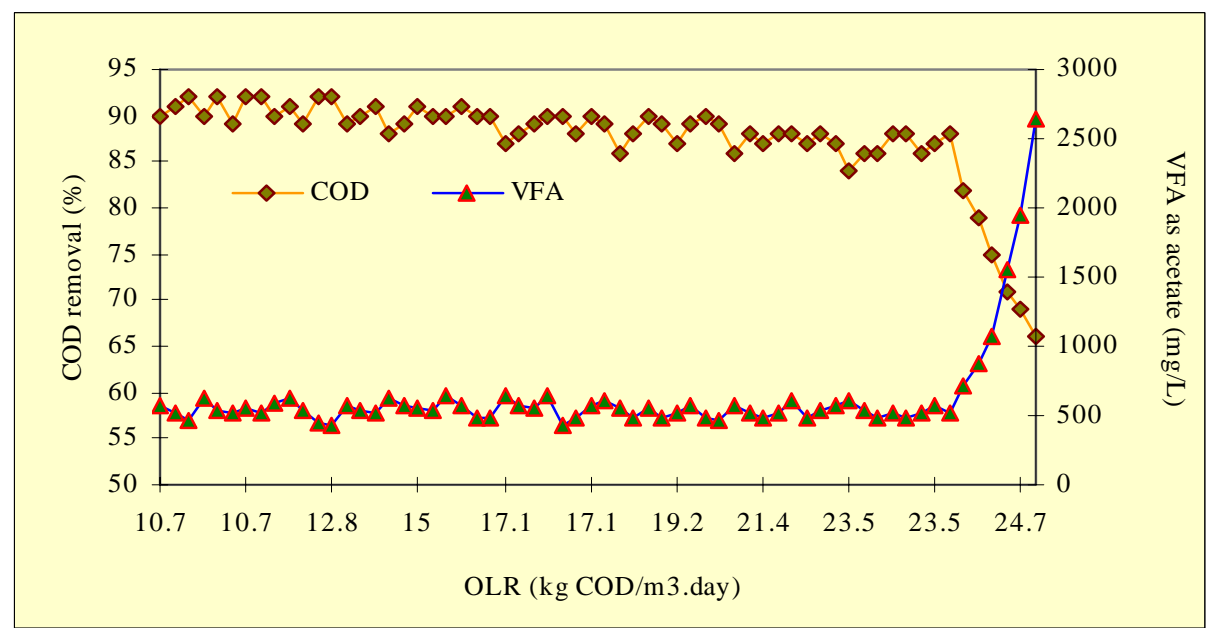

Fig. 5: Influence of OLR on COD removal and VFA accumulation during the treatment of synthetic Sago wastewater in HUASB 


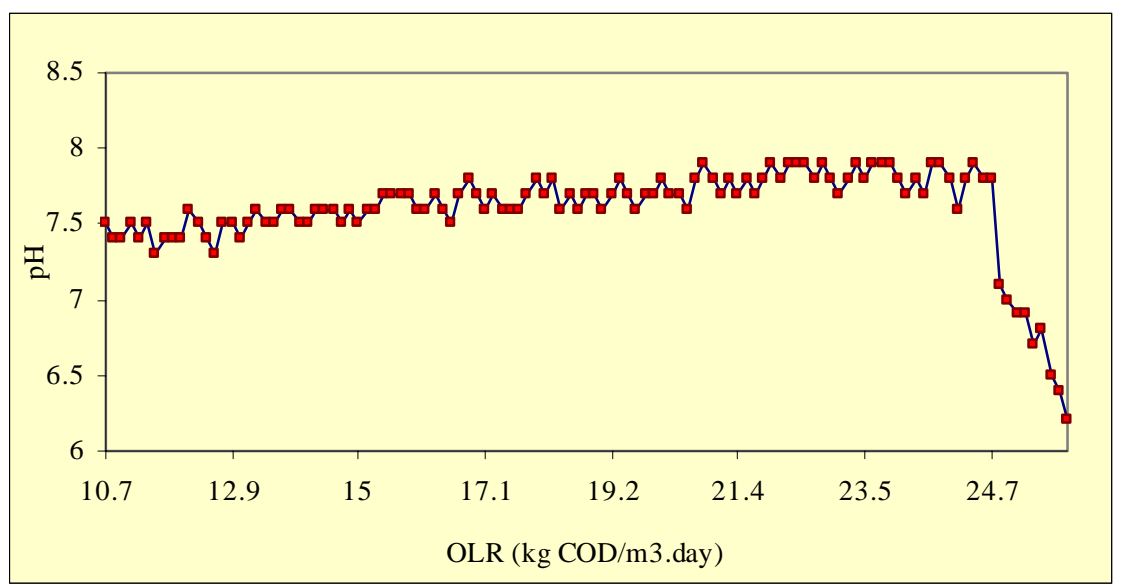

Fig. 6: Influence of OLR on pH during the treatment of synthetic Sago wastewater in HUASB

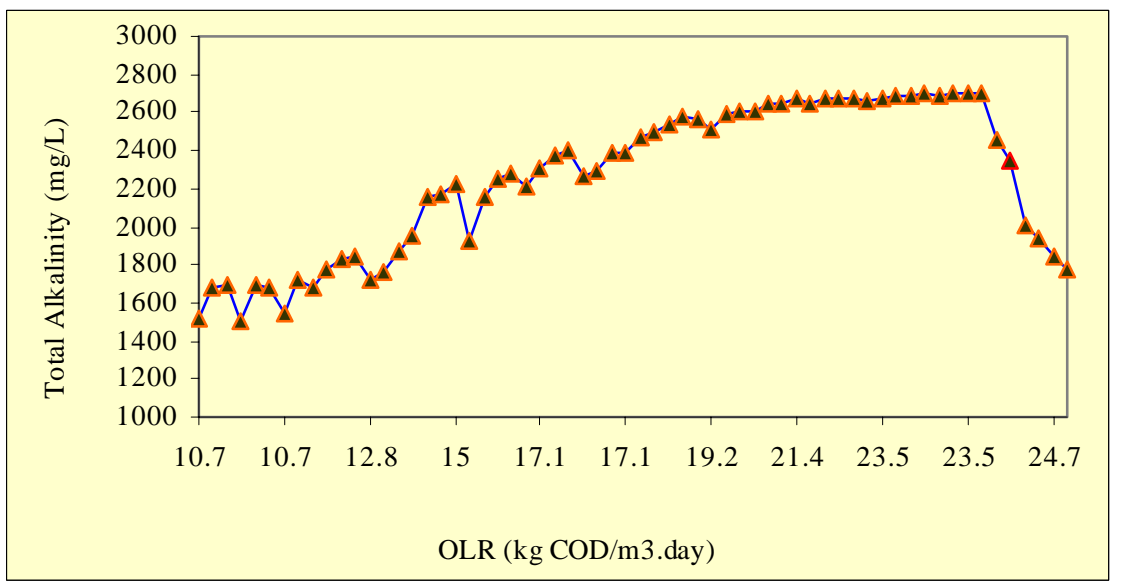

Fig. 7: Influence of OLR on alkalinity during the treatment of synthetic Sago wastewater in HUASB

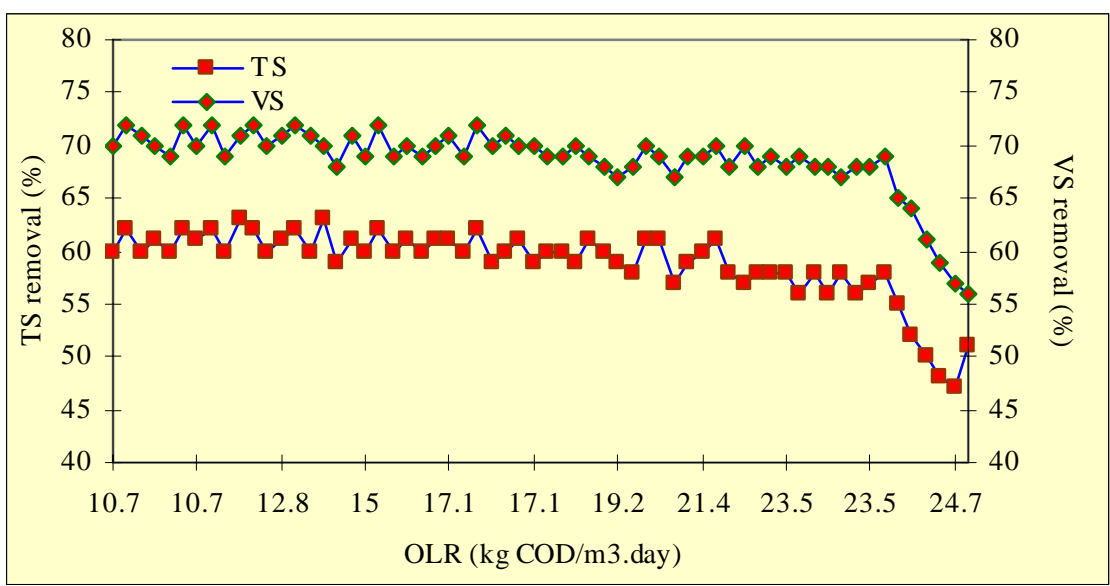

Fig. 8: Influence of OLR on removal of TS and VS during the treatment of synthetic Sago wastewater in HUASB 
The methane content in the biogas at different phases varied from $55 \pm 2$ to $61 \pm 2 \%$, which is comparable to 52 to $63 \%$, reported during the treatment of Sago wastewater in anaerobic filter by Khageshan and Govindan (1995). Influence of OLR on COD removal and VFA concentration in the medium during the treatment of Sago wastewater is illustrated in Fig. 5 and Table 2. It is evident from the Fig. that at an OLR of $10.7 \mathrm{~kg} \mathrm{COD} / \mathrm{m}^{3}$.day the COD removal was $91 \%$. As the OLR increased, the COD removal exhibited a gradual decrease; at an OLR of $23.5 \mathrm{~kg} \mathrm{COD} / \mathrm{m}^{3}$. day the COD removal was $87 \%$ and as mentioned elsewhere in the discussion the gas production was maximum at this OLR. The COD removal touched an all time low of 70\% when the OLR was increased to $24.7 \mathrm{~kg} \mathrm{COD} / \mathrm{m}^{3}$.day. During the stable operational phase (OLR: 10.7 to 23.5 $\mathrm{kg} \mathrm{COD} / \mathrm{m}^{3}$.day) of the reactor, the VFA (as acetate) levels in the medium varied from 420 to $640 \mathrm{mg} / \mathrm{L}$. VFA started building up in the wastewater as the digestion proceeded and the maximum concentration of $2650 \mathrm{mg} /$ L was recorded at an OLR of $24.7 \mathrm{~kg}$ COD $/ \mathrm{m}^{3}$.day. VFA has been recognized as one of the important intermediates during the anaerobic digestion (Wang et al., 1999; Ahring Angelidaki 1997) and is considered a central parameter for anaerobic treatment (Ahring and Angelidaki, 1995; Pind et al., 1999; 2002). The impact of VFA accumulation was reflected in the marked decrease of COD removal from 86 to $68 \%$ when the OLR was increased to $24.7 \mathrm{~kg} \mathrm{COD} / \mathrm{m}^{3}$.day. Working on synthetic dairy wastewater using UASB, Fang et al., (1994) have reported a VFA concentration of over $2500 \mathrm{mg} / \mathrm{L}$ responsible for souring of the anaerobic reactor. Fig. 6 presents variations in $\mathrm{pH}$ during the treatment. The $\mathrm{pH}$ of the treated wastewater was in the range of $7.5-7.9$ up to an OLR of $23.5 \mathrm{~kg} \mathrm{COD} / \mathrm{m}^{3}$.day which is indicative of the satisfactory condition of the reactor. It is known that $\mathrm{pH}$ less than 6.8 and greater than 8.3 would cause souring of the reactor during anaerobic digestion (Wheatly 1991). The $\mathrm{pH}$ of the wastewater dropped to 6.2 when the OLR was increased to $24.7 \mathrm{~kg} \mathrm{COD} / \mathrm{m}^{3}$.day from $23.5 \mathrm{~kg} \mathrm{COD} / \mathrm{m}^{3}$.day. Alkalinity of the effluent increased from $1510 \mathrm{mg} / \mathrm{L}$ at an OLR of $10.7 \mathrm{~kg} \mathrm{COD} / \mathrm{m}^{3}$.day to $3120 \mathrm{mg} / \mathrm{L}$ at an OLR of $23.5 \mathrm{~kg} \mathrm{COD} / \mathrm{m}^{3}$.day (Fig. 7). Increase in OLR beyond this level caused a decrease in alkalinity in the wastewater. Alkalinity is known to be a critical buffering factor for neutralizing VFA during methanogenesis (Pohland 1969). Decrease in alkalinity obviously affects the buffering capacity and leads to dropping down of
pH. Fig. 8 and Table 2 presents the influence of OLR on the removal of TS and VS from the Sago wastewater during the treatment phase. The determination of VS is useful in control of wastewater treatment plant operation as it offers rough approximation of the amount of organic matter present in the solid fraction of wastewater (Standard Methods, 1988). Under stable operation conditions (up to an OLR of $23.5 \mathrm{~kg}$ COD/ $\mathrm{m}^{3}$.day) the removal of TS and VS in the wastewater was in range of $61-57 \%$ and $70-67 \%$, respectively. Like all other parameters the removal efficiency of both TS and VS decreased drastically when the OLR was increased from 23.5 to $2.4 .7 \mathrm{~kg} \mathrm{COD} / \mathrm{m}^{3}$.day; the respective values for TS and VS being 50 and $61 \%$. Table 3 presents the utilization pattern of nutrients (organic nitrogen and phosphorous) and the removal of sulphate during the treatment of Sago wastewater. From the Figs. it is evident that the utilization of organic nitrogen was markedly higher than that of phosphorus. Higher utilization of nitrogen in comparison with phosphorous during the anaerobic treatment of Sago wastewater has been reported by Subramanian and Sastry (1989) also. Utilization of organic nitrogen fell from 39 to $36 \%$ when the OLR was increased from 10.7 to $23.5 \mathrm{~kg} \mathrm{COD} / \mathrm{m}^{3}$.day. Similarly, the phosphorous utilization fell from $22 \%$ at an OLR of $10.7 \mathrm{~kg} \mathrm{COD/}$ $\mathrm{m}^{3}$.day to $16 \%$ at an OLR of $23.5 \mathrm{~kg} \mathrm{COD} / \mathrm{m}^{3}$.day. The decrease in nutrient utilization at higher OLRs can be attributed to higher flow rate of the wastewater and the consequent reduction in contact time between nutrients and microbes as well as the nutrient washout. The removal of sulphate in the wastewater was in the range of $84-81 \%$. The chloride concentration in the effluent remained unaffected during the treatment.

\section{DISCUSSION AND CONCLUSION}

The higher loading rate achievable (23.5 kg COD/ $\mathrm{m}^{3}$.day observed) in the present study can be attributed to the structural modifications effected to UASB and also the filter material used. For instance, working on the treatment of Sago wastewater using AF, with granite stones as filter medium Subrahmanyam and Sastry (1989) have reported that the gas production decreased at an OLR of $16 \mathrm{~kg} \mathrm{COD} / \mathrm{m}^{3}$.day. Khageshan and Govindan (1995) have reported that beyond an OLR of $11.6 \mathrm{~kg} \mathrm{COD} / \mathrm{m}^{3}$.day, gas production decreased during the treatment of synthetic Sago wastewater using anaerobic filter with basalt stone chips as filter medium. In contrast to the present observations, 
Table 2: Performance of the HUASB reactor treating synthetic Sago wastewater

\begin{tabular}{ccccccccc}
\hline $\begin{array}{c}\text { Sl. } \\
\text { No. }\end{array}$ & $\begin{array}{c}\text { Digestion } \\
\text { period } \\
\text { (days) }\end{array}$ & $\begin{array}{c}\text { OLR } \\
\left(\mathrm{kg} \mathrm{COD} / \mathrm{m}^{3} \text {.day) }\right.\end{array}$ & $\begin{array}{c}\text { Normalized methane } \\
\text { production (NMP) } \\
\mathrm{m}^{3} \mathrm{CH}_{4} / \text { Kg COD. day }\end{array}$ & $\begin{array}{c}\text { Methane } \\
(\%)\end{array}$ & $\begin{array}{c}\mathrm{COD}^{*} \\
\text { removal } \\
(\%)\end{array}$ & $\begin{array}{c}\text { VFA* } \\
(\mathrm{mg} / \mathrm{L})\end{array}$ & $\begin{array}{c}\text { TS* } \\
\text { removal } \\
(\%)\end{array}$ & $\begin{array}{c}\text { VS* } \\
\text { removal } \\
(\%)\end{array}$ \\
\hline 1 & $131-145$ & 10.7 & 0.110 & 61 & 91 & 540 & 61 & 70 \\
2 & $146-160$ & 12.8 & 0.117 & 62 & 90 & 531 & 61 & 70 \\
3 & $161-175$ & 15.0 & 0.124 & 62 & 90 & 560 & 60 & 69 \\
4 & $176-190$ & 17.1 & 0.133 & 67 & 89 & 562 & 60 & 70 \\
5 & $191-205$ & 19.2 & 0.128 & 60 & 89 & 515 & 59 & 68 \\
6 & $206-220$ & 21.4 & 0.133 & 61 & 87 & 537 & 58 & 68 \\
7 & $221-235$ & 23.5 & 0.139 & 62 & 87 & 531 & 57 & 67 \\
8 & $236-245$ & 24.7 & 0.065 & 54 & 70 & 1234 & 50 & 61 \\
\hline
\end{tabular}

*Average of 6 readings at each OLR

Table 3: Utilization of nutrient nitrogen phosphorous and sulphate during the treatment of Sago wastewater

\begin{tabular}{cccccccccc}
\hline $\begin{array}{c}\text { OLR } \\
\left(\mathrm{kg} \mathrm{COD} / \mathrm{m}^{3} . \text { day }\right)\end{array}$ & $\begin{array}{c}\text { Influent } \\
(\mathrm{mg} / \mathrm{L})\end{array}$ & $\begin{array}{c}\text { Effluent } \\
(\mathrm{mg} / \mathrm{L})\end{array}$ & $\begin{array}{c}\text { Removal } \\
(\%)\end{array}$ & $\begin{array}{c}\text { Influent } \\
(\mathrm{mg} / \mathrm{L})\end{array}$ & $\begin{array}{c}\text { Effluent } \\
(\mathrm{mg} / \mathrm{L})\end{array}$ & $\begin{array}{c}\text { Removal } \\
(\%)\end{array}$ & $\begin{array}{c}\text { Influent } \\
(\mathrm{mg} / \mathrm{L})\end{array}$ & $\begin{array}{c}\begin{array}{c}\text { Effluent } \\
(\mathrm{mg} / \mathrm{L})\end{array} \\
(\%)\end{array}$ & $\begin{array}{c}\text { Removal } \\
(\%)\end{array}$ \\
\hline 10.7 & $80.1 \pm 2$ & $48.9 \pm 2$ & 39 & $26.7 \pm 0.2$ & $20.8 \pm 0.1$ & 22 & $38.7 \pm 1$ & $6.2 \pm 0.2$ & 84 \\
12.8 & $95.8 \pm 2$ & $59.4 \pm 1$ & 38 & $31.9 \pm 0.1$ & $24.9 \pm 0.2$ & 22 & $46.3 \pm 1$ & $7.9 \pm 0.2$ & 83 \\
15.0 & $111.4 \pm 3$ & $68.0 \pm 2$ & 39 & $37.1 \pm 0.2$ & $29.0 \pm 0.1$ & 22 & $53.9 \pm 2$ & $9.7 \pm 0.2$ & 82 \\
17.1 & $127.1 \pm 3$ & $78.8 \pm 2$ & 38 & $42.4 \pm 0.1$ & $34.3 \pm 0.2$ & 19 & $61.4 \pm 1$ & $9.8 \pm 0.2$ & 84 \\
19.2 & $142.7 \pm 2$ & $88.5 \pm 3$ & 38 & $47.6 \pm 0.2$ & $39.0 \pm 0.2$ & 18 & $69.0 \pm 2$ & $13.1 \pm 0.2$ & 81 \\
21.4 & $158.4 \pm 5$ & $101.4 \pm 3$ & 36 & $52.8 \pm 0.2$ & $43.8 \pm 0.3$ & 17 & $76.6 \pm 1$ & $14.5 \pm 0.2$ & 81 \\
23.5 & $174.1 \pm 2$ & $111.4 \pm 4$ & 36 & $58.0 \pm 0.3$ & $48.7 \pm 0.2$ & 16 & $84.1 \pm 1$ & $16.0 \pm 0.2$ & 81 \\
\hline
\end{tabular}

Saravanane et al., (2001) have reported a very high OLR of $60.5 \mathrm{~kg} \mathrm{COD} / \mathrm{m}^{3}$.day during the start up phase of treatment of synthetic Sago wastewater using a fluidized bed reactor. Interestingly, the efficiency of this reactor in terms of COD removal (82\%) is lower than the value recorded during the present study (92\%) during the start up. Further comparison between these two studies is not possible in the absence of data on HRT maintained by Saravanane et al., (2001). The anaerobic treatment of Sago wastewater using the Hybrid Upflow Anaerobic Sludge Blanket indicated promising results. The reactor could be operated at a considerably higher OLR for $23.5 \mathrm{~kg} \mathrm{COD} / \mathrm{m}^{3}$.day, which is twice the loading rate suggested for the treatment in Anaerobic Filter. Further, it was possible to achieve higher COD removal (86\%) and considerable generation of biogas ( $28.7 \mathrm{~m}^{3} /$ day) at a HRT as low as $5.6 \mathrm{~h}$. The results are significant, especially in the context of wastewater treatment in tropical developing countries, where reactor design with low HRT and high OLR would be a technologically viable and economically affordable option.

\section{ACKNOWLEDGEMENT}

Authors are very much thankful to Indo-German project at Centre for Environmental Studies for providing facilities under their project.

\section{REFERENCE}

Ahring, B. K. and Angelidaki, I., (1995)., Volatile fatty acids as indicators of process imbalance in anaerobic digestion. Appl. Microbiol. Biotechnol., 43, 559-565.

Ahring, B. K. and Angelidaki, I., (1997)., Monitoring and controlling the biogas process. Proceeding at 8 th international conference on anaerobic digestion. Sendai, Japan, 1, 40-45.

Bull, M. A. Sterritt, R. and Lester, J. N., (1983)., Influence of COD, Hydraulic, temperature, and $\mathrm{pH}$ shocks on stability of an unheated fluidized bed reactor. J. Chem. Tech. Biotechnol., 33, 221-230.

Coates, J. and Colleran, E., (1990)., Effect of initial agitation on the start up and operational performance of anaerobic hybrid reactors treating a synthetic feed. Process Biochem. Biotechnol., 10, 162-171.

Elmitwalli, T. A., Sklyar, V., Zeeman, G. and Lettinga, G., (2002a)., Low temperature pretreatment of domestic sewage in an anaerobic hybrid or an anaerobic filter reactor. Biores. Technol., 52, 233-239.

Elmitwalli, T. A., Kim, L. T., Zeeman, G. and Lettinga, G., (2002b)., Treatment of domestic sewage in a tow step 
anaerobic filter/anaerobic hybrid system at low temperature. Wat. Res., 36, 2225-2232.

Fang, H. H. P., Guohua, L., Jinfu, Z., Bute, S. and Guowei, G., (1994)., Treatment of brewery effluent by UASB process. J. Environ. Eng., 116, 454-460.

Guiot, S. R. and Van den Berg, L., (1984)., Dynamic performance of an anaerobic reactor combining an upflow sludge blanket and a filter for the treatment of sugar waste. Proceedings of the 39th annual Purdue Industrial Waste Conference, Lafayette, Indian, 705-717.

Guiot, S. R. and Van den Berg, L., (1985)., Performance of an upflow anaerobic reactor combining a sludge blanket and a filter treating sugar waste. Biotechnol. Bioeng., 27, 800806.

Hentry, M. P., Donlon, B. A., Lens, P. N. and Colleran, E. M., (1996)., Use of anaerobic hybrid reactor for treatment of synthetic pharmaceutical wastewaters containing organic solvents. J. Chem. Tech. Biotech., 66, 251-264.

Hickley, R. F., Wu, W. M., Viega, M. C. and Jone, R. (1991). Start up, operation monitoring and control of high rate anaerobic treatment systems. Wat. Sci. Technol., 24, 207256.

Hysman, P., Van Meenen, P., Van Asche, P. and Verstraete, W., (1985)., Factors affecting the colonization of non-porous and porous packing materials in model upflow methane reactors. Biotechnol. Lett., 5 (9), 643-648.

Khageshan, P. and Govindan, V. S., (1995)., Anaerobic filter for treatment of Sago wastewater. Proceedings of 4 th national symposium on Environment, Chennai, India, 248252.

Murthy, Y. S. and Patel, M. D., (1961)., Treatment and disposal of Sago wastes. Central Public Health Engineering Research Institute. India.

Pescod, M. B. and Thanh, N. C., (1977)., Treatment alternatives for wastewaters from the tapioca starch industry. Wat.Sci.Technol., 9 (3), 63-574.

Pind, E. P., Angelidaki, I. and Ahring, B. K., (1999)., The use of VFA measurement as process indicators in anaerobic reactors treating manure. II international symposium on anaerobic digestion of solid waste, Barcelona, 41-44.

Pind, F. P., Angelidaki, I. and Ahring, B. K., (2002)., Dynamics of the anaerobic process: Effects of volatile fatty acids. Biotechnol. Bioeng., 82 (7), 791- 801.

Pohland, F. F. (1969)., High rate digestion control techniques for evaluating acid-base equilibrium. Proc. $24^{\text {th. }}$ Industrial waste conference, Purdue University, Lafayette, Indiana, 91-993.

Salkinoja-Salonen, M. S., Nyns, E. J., Sutton, P. M., Van den Berg, L. and Wheatley, A. D., (1983)., Starting up of an anaerobic fixed film reactor. Wat. Sci. Technol., 15 (8), 305-308.

Saravanane, R., Murthy, D. V. S. and Krishniash, K., (2001). Anaerobic treatment and biogas recovery for Sago wastewater management using a fluidized bed reactor. Wat. Sci. Technol., 44 (6), 141-147.

Saroja, K. and Sastry, C. A., (1972). Report on treatment of Sago wastes. National Environmental Engineering Research Institute, India.

Sastry, C. A. and Mohan, G. J., (1963)., Anaerobic digestion of industrial wastes. Indian J. Environ. Health, 5 (3), 20-25.

Sastry, C. A., Murahari, R. and Saroja, K., (1964)., Studies on the treatment of Sago mill wastewater. Seminar on Environmental Pollution, Kerala, India.

Shapiro, M. and Switzenbanum, M. S., (1984)., Initial anaerobic bioflim development. Biotechnol. Lett., 6, 729-734.

Shivayogimath, C. B. and Ramanujam, T. K., (1999)., Treatment of distillery spent wash by hybrid UASB reactor. Bioprocess Engineering. 21, 255-259.

Standard Methods for the Examination of Water and Wastewater. (1998). 20 $0^{\text {th. }}$ Ed., American Public Health Association, Washington.

Subrahmanyam, Y. V. and Sastry, C. A., (1989)., Attached versus suspended biomass activity in upflow anaerobic filters. J. Ins. Eng., 9, 27-32.

Tilche, A. and Vieira, S. M. M., (1991)., Discussion reports on reactor design of anaerobic filters and sludge bed reactors. Wat Sci Technol., 24, 193-206.

Tongkasane, C. (1970)., Anaerobic treatment of tapioca starch Wastewater. Wat. Wast. treat., 13, 392-398.

Van Haandel, C. and Lettinga, G., (1994)., Anaerobic sewage treatment: A practical guide for regions with a hot climate. Wiley publishers, U.K.

Wang, Q. H., Kuninobu, M., Ogawa H. I. and Kato, Y., (1999)., Degradation of volatile fatty acids in highly efficient anaerobic digestion. Biomass and Bioenergy,16, 407-416.

Wheatly, A., (1991)., Anaerobic digestion: A waste treatment technology. Elsevier Science publishers Ltd. 


\section{AUTHOR(S) BIOSKETCHES}

Rajesh Banu, J., M.Sc., M.Phil., Ph.D., is a lecturer in the Department of Biotechnology, Jeppiaar Engineering College and a Ph.D. research student in environmental biotechnology at the Centre for Environmental Studies, Anna University, Chennai, India. E-mail: rajeshces@gmail.com

Kaliappan, S., B.E., M.E., Ph.D., is a professor in Civil engineering and Director of Institute of Remote Sensing at Anna University, Chennai, India. E-mail: drkalsun@yahoomail.com

Beck, D., is a professor and senior advisor in Indo-German project at Centre for Environmental Studies, Anna University, Chennai, India. E-Mail: diter.bck@tonline.de

This article should be referenced as follows:

Rajesh Banu, J., Kaliappan. S. and Beck, D., (2006). High rate anaerobic treatment of Sago wastewater using HUASB with PUF as carrier. Int. J. Environ. Sci. Tech., 3 (1), 69-77. 